\title{
Strengths-Based Practice and Motivational Interviewing
}

\author{
Trevor Jay Manthey \\ Bryan Knowles \\ Dianne Asher \\ Stephanie Wahab
}

\begin{abstract}
There has been recent concern that many practices and programs erroneously claim to be strengths-based. In reaction some have called for researchers to make systematic comparisons to the tenets of strengths-based practice (SBP) before making the contention that an intervention is strengths-based. Motivational interviewing (MI) is an intervention which has been described as being strengths-based; however, no systematic efforts have yet been made to compare the two. This article takes a methodical approach to comparing SBP and MI to determine level of cohesion and how they might be used together. A case-example is used to illustrate how MI and SBP may be used in conjunction and implications for social work practice and education are discussed.
\end{abstract}

Keywords: Strengths, strengths-based practice, intervention, motivation, motivational interviewing

\section{INTRODUCTION}

There has been recent concern that social work agencies, programs, practices, and therapies that claim to be strengths-based often misperceive what it means to operate from a strengths-based practice (SBP) (Rapp, Saleebey, \& Sullivan, 2005). Operating from a SBP does not mean someone is merely being nice or ignoring problems, rather SBPs contain distinct ideological underpinnings and principles which guide practice (Saleebey, 2006). Many interventions which make claim to being strengths-based do not make a systematic effort to corroborate what they actually do with authentic SBP. Conducting SBP requires dedication and a depth of commitment and often the principles, though simple on the surface, are complex in operation (e.g. Marty, Rapp, \& Carlson, 2001). In response to the discrepancy between what is sometimes professed about interventions and what actually occurs, Rapp et al. (2005) developed six standards to evaluate whether or not a practice is strengths-based.

Motivational interviewing (MI), an intervention used to facilitate behavior change, has gained international attention and is often described as a SBP (Chung, Burke, \& Goodman, 2010; Clark, 2006; Corcoran, 2005; van Wormer \& Davis, 2008). While articles have alluded to consistencies between MI and SBP (e.g. Clark, 2001; 2005), no published methodical efforts have yet been made to link the two. The authors believe MI

Trevor Jay Manthey, LMSW, is a graduate research assistant, consultant, trainer, and doctoral student, Bryan Knowles, LMSW , is a consultant and trainer for the Integrated Dual Disorders Treatment (IDDT) model, and Dianne Asher, LSCSW, is the Project Manager for IDDT, all in the School of Social Welfare at the University of Kansas in Lawrence, KS. Stephanie Wahab, Ph.D., is an Associate Professor in the School of Social Work at Portland State University.

Copyright @ 2011 Advances in Social Work Vol. 12 No. 2 (Fall 2011), 126-151 
does fit into a strengths-based paradigm and the goal of this article is to engage the challenge issued by Rapp et al. (2005) in Advances in Social Work by systematically comparing MI with SBP.

We begin by reviewing the origins of both approaches. This review is followed by a systematic examination of the principles of MI through the lens of the qualifying standards put forth by Rapp et al. (2005) that assesses the goodness of fit of MI to the principles of SBP as described by Saleebey (2006). A potential reciprocal relationship is acknowledged and a case-scenario is used to describe how both SBP and MI can be used together. Implications are discussed for social work education and practice.

\section{ORIGINS AND DEFINITIONS}

Strengths-based practice has been conceptualized as an overarching perspective and as a set of principles. Specific models such as Strengths-Based Case Management (SBCM) have also been developed (Brun \& Rapp, 2001; Rapp \& Goscha, 2006). These multiple levels of conceptualization create difficulty in drawing definitions and comparisons (Probst, 2009) and some have critiqued SBP because it can be difficult to operationalize (McMillen, Morris, \& Sherraden, 2004; Staudt, Howard, \& Drake, 2001). For the purpose of this article we draw specifically from the principles guiding SBP as defined by Saleebey (2006) and the qualifying standards put forth by Rapp et al. (2005).

\section{Strengths-Based Practice}

A definition of SBP put forth by Saleebey (2010) posits that operating from a SBP means that "everything you do as a helper will be based on facilitating the discovery and embellishment, exploration, and use of clients' strengths and resources in the service of helping them achieve their goals and realize their dreams (p. 1)” In addition, central to SBP is the belief that clients are most successful at achieving their goals when they identify and utilize their strengths, abilities, and assets (Rapp, 2006). SBP assists clients in recognizing and utilizing the strengths and resources they may not recognize within themselves, thus aiding clients in regaining power over their lives (Greene, Lee, \& Hoffpauir, 2005).

Although aspects of SBP have been discussed in the social work literature periodically throughout much of its history, strengths-based work wasn't formalized into a set of practice principles until the 1980s (Rapp et al., 2005). The formalization came in response to the pathology-laden treatments available for individuals with psychiatric disorders prevalent at that time (Weick, Rapp, Sullivan, \& Kisthardt, 1989). SBP was a stance taken to oppose a mental health system that overly focused on diagnosis, deficits, labeling, and problems (Saleebey, 2000; 2001). Initially implemented in casemanagement, SBP then moved into other areas of social work and the helping professions (Saleebey, 1996).

SBP contains explicit practice principles; however, SBP is not explicit about what skills workers should use. It describes processes that are important but doesn't necessarily describe in detail how to practice those processes. Instead, SBP can be perceived as a way of conducting oneself during any practice interaction (Saleebey, 
2006). SBP can be used in a majority of the situations workers may find themselves in because it is a framework by which one sees and interacts with others. A profound belief in an individual's potential is intrinsic to any strengths-based interaction (Rapp \& Goscha, 2006). Strengths-based practice begins with understanding what goals and dreams a client has and then helping the client to reflect on the possibilities and hopes that their lives hold (Saleebey, 2006). Helping clients reflect on their goals and dreams facilitates the discovery and development of new possibilities for, and change toward, a better quality of life (Saleebey, 2006).

\section{Motivational Interviewing}

Motivational interviewing was originally developed in the addictions field in the 1980 s as an alternative to the coercive and confrontational approaches used in the substance abuse field at that time (Miller \& Rollnick, 2002). MI has since moved into many helping fields, including social work. William Miller reported that the formulation of MI was facilitated through individuals in Norway asking him why he interacted with clients in some ways (that produced positive results) rather than others (Miller \& Rose, 2009). This forced Miller to make explicit the approach he had learned from his clients. Therefore, MI was developed through practice wisdom first (e.g., what appeared to be working to help facilitate change) and then moved toward attaching theory about why it worked later (Miller \& Rose, 2009), as is consistent with a practice-based evidence research methodology (e.g., Tilsen \& Nylund, 2008).

Miller and Rollnick (2002) defined MI as "a client-centered, directive method for enhancing intrinsic motivation to change by exploring and resolving ambivalence” (p. 25). This approach accepts that ambivalence toward behavioral change is normal. Argumentation is avoided because trying to persuade a person to make a behavioral change usually results in the person verbally defending the status quo. Intrinsic motivation is achieved when a person sees a conflict between their current behavior and other goals or values that they hold. The role of the counselor, therefore, is to explore those goals and values and to elicit statements or perspectives that support behavioral change (Miller \& Rollnick, 2002).

There are a variety of skills outlined in the use of MI, and an explanation of all these skills is beyond the scope of this article. However, one interesting and critical facet of MI is that the intervention outlines not just what skills to use but how the skills are to be implemented. There is a spirit associated with MI that grounds how a counselor approaches people. Miller and Rollnick (2002) are clear that the spirit of MI is integral to its successful practice, as they have encountered practitioners and trainers “mimicking...component techniques without understanding their overall context” (p. 33).

The spirit of MI is comprised of three components: collaboration, evocation, and autonomy. These components are described as follows:

1. Collaboration. Counseling involves a partnership that honors the client's expertise and perspectives. The counselor provides an atmosphere that is conducive rather than coercive to change (p. 35). Miller and Rollnick contrast collaboration to its opposite approach: Confrontation, in which overriding the 
client's perspective and correcting his or her view of reality are central components. An individual may decide to personally confront behavior change issues during the MI process; however, it is not the role of the worker to be confrontational.

2. Evocation. The resources and motivation for change are presumed to reside within the client. Intrinsic motivation for change is enhanced by drawing on the client's own perceptions, goals, and values. Evocation is in turn compared with education, in which there is an assumption of a deficit in the client's "knowledge, insight, and/or skills" that must be corrected by the counselor (p. 35). Education, such as normative feedback, may be a tool used within MI, but it is not the goal.

3. Autonomy. The counselor affirms the client's right and capacity for self-direction and facilitates informed choice. Autonomy is contrasted with authority, in which the client's role is to be told what he or she should do.

These elements of the spirit of MI are important when considering how this approach may or may not be consistent with strengths-based practice.

\section{SYSTEMATIC COMPARISON}

This article compares $\mathrm{MI}$ and SBP to assess the commensurability of the two approaches and to determine the degree to which MI is consistent with SBP. It is important to make this comparison in order to respond to the call for individuals to make systematic efforts to corroborate a given intervention with SBP before making the contention that an intervention is strengths-based (Rapp et al., 2005). Conducting this comparison is also important because not every intervention is appropriate for social work (even with empirical support) if the intervention is not consistent with social work values and ethics. Recognizing strengths is a key component of social work's code of ethics (NASW, 2006). Therefore, comparing MI to SBP is an important step in determining if the intervention is appropriate for social work.

Comparison of SBP and MI occurred across eight domains which were created by combining Rapp et al.'s (2005) standards and Saleebey's (2006) principles of SBP. If a standard or principle overlapped we combined them into one domain. Three researchers were used as a panel to determine if a standard or principle was overlapping. Motivational interviewing was then compared to each domain of SBP. If there was disagreement, meetings continued to be held and concepts studied until consensus was reached. Motivational interviewing was rated explicitly consistent, philosophically consistent, or not consistent to each of the developed SBP domains. The three-level rating scale (explicitly, philosophically, or not consistent) was developed by the research team in order to provide for a more nuanced analysis than a simple yes/no regarding consistency. At the conclusion of each of the following comparative sections a sentence is included which describes what rating motivational interviewing was given for the SBP domain described. 


\section{Goal Orientation}

Strengths-based practice is goal oriented. Encouragement is given to individuals to set goals they would like to achieve in their lives. Goal setting becomes a foundation or backdrop for which strengths are assessed and mobilized (Saleebey, 2006). There are some situations where a worker helps an individual to define and articulate his or her goal(s); however, it is still the individual's values that drive the goal setting process (Rapp \& Goscha, 2006).

Motivational interviewing is focused on the exploration of goals and values. Individuals are invited to explore what their ultimate goals are and how they imagine themselves achieving them (e.g. Corrigan, McCracken, \& Holmes, 2001). Exploring what values are important to an individual is also incorporated into MI. The goals and values are elicited from the individual and not imposed upon them from outside (Miller \& Rollnick, 2002). The goal setting process is person-centered (Rollnick, Miller, \& Butler, 2008).

Conclusion: Motivational interviewing is explicitly consistent with SBP's goal orientation principle.

\section{Strengths Assessment}

Strengths-based practice contains a systematic means of assessing strengths (Rapp et al., 2005). Assessment for, and documentation of, strengths occurs in a methodical way that avoids a primary focus on problems, pathology or deficits (e.g. Rapp \& Goscha, 2006). The means to overcoming barriers to goal attainment are seen as being tied to an individual's strengths such as talents, assets, resources, and skills. Attention is also given to what is already working, searching for instances when there are exceptions to problems, and identifying coping strategies that an individual has already obtained. Focus is more often on the current situation rather than past pathology; although, the past can be explored for talents, resources, and assets (Saleebey, 2006).

Motivational interviewing provides workers with skills to assess client confidence in their ability to make behavioral change (Miller \& Rollnick, 2002). When a client lacks confidence to make behavior change, the MI practitioner uses skills to elicit clients' belief in their own ability. For instance, individuals using MI facilitate discussion which enables individuals to look back over their lives and identify past successes (Miller \& Rollnick, 2002). What is working currently and how individuals can imagine things working better are also explored. Affirmation skills are developed which allow workers to specifically identify and affirm strengths, encourage autonomy, and provide support (Rollnick et al., 2008). Excessive exploration of the history of the problem is discouraged; rather the focus is on past success, self-confidence and self-efficacy (Rollnick et al., 2008).

Conclusion: Motivational interviewing is philosophically consistent with the SBP principle of strengths assessment. 


\section{Environmental Resources}

Strengths-based practice sees the environment as rich in resources. It is highlighted that the natural community is the principal source of resources, opportunities, people, and supports (Saleebey, 2006). A tenet of SBP is that often goal attainment occurs through the matching of client desires and strengths with naturally occurring resources in the environment (Rapp \& Goscha, 2006). Strengths-based practice assumes every individual, group, family, and community has strengths and resources (Saleebey, 2006). In strengthsbased practice explicit methods link client and environmental strengths to goal attainment. After the goal has been identified and strengths have been assessed, a clear means for utilizing and mobilizing strengths is identified. The identification and use of resources, therefore, becomes essential and may be one of the most important principles of SBP (e.g. Davidson \& Rapp, 1976). The plan is derived from the goals and strategically incorporates strengths (Rapp \& Goscha, 2006). The idea is to build from strengths and aspirations, agree on a set of goals, and match these goals with natural resources in the community.

The idea within motional interviewing is to focus on exploring client goals and values, build motivation to achieve the explored goals and values, determine how current behavior fits or doesn't fit with goals and values, and develop a change plan based on client preferences. The change plan is meant to help individuals live more consistently with the values they hold dear and achieve their goals. Both MI and SBP assume that every individual group or family has strengths. Motivational interviewing assumes individuals know their personal environment and its resources better than the worker (Miller \& Rollnick, 2002). It is central to MI that the plan be developed based on how individuals see themselves most likely succeeding (Rollnick et al., 2008). It is up to the worker to listen carefully for strengths and resources and strategically affirm them or their use (Miller \& Rollnick, 2002). In this way, the worker helps the individual to selfidentify and use their strengths and environmental resources in a productive fashion within their change plan. Therefore, the change plans facilitated through MI often include naturally occurring resources, such as family members, friends, or a community group. The worker who uses MI is also purposeful in eliciting client strengths and change language in order to help mobilize confidence and importance for behavior change (Miller \& Rollnick, 2002).

Conclusion: $M I$ is philosophically consistent with the SBP principle of using environmental resources.

\section{The Relationship}

The strengths-based relationship is hope-inducing. The relationship is clearly attuned to increasing the hopefulness of the individual, family or group (Rapp et al., 2005). Being accepting, empathetic, and having a collaborative purpose are all part of the strengthsbased relationship (Saleebey, 2006). The hope inducing qualities of the strengths-based relationship can be destroyed through spirit-breaking behaviors, such as labeling, having a problem or diagnostic focus, or pathologizing (Deegan, 1990). The focus of the helping process is on strengths, interests, knowledge, and capabilities, not on diagnosis, deficits, 
symptoms, and weaknesses. The relationship is also empowering in that it increases individuals' perceptions of their abilities, increases choices and options, and increases confidence to choose (Rapp \& Goscha, 2006).

The motivational interviewing relationship facilitates hope, confidence, and motivation for change. As noted previously, MI provides skills for supporting an individual's self-efficacy which often can be hope-inducing (Miller \& Rollnick, 2002). Self-efficacy can be defined as a person's belief in his or her personal competence and ability to achieve his or her goals. The MI spirit includes maintaining a positive and supportive relationship that emphasizes the evocation of an individual's ideas, increasing an individual's autonomy, and collaboration (Miller \& Rollnick, 2002). MI also focuses on increasing the importance of, and confidence to, change. Attention is given to how individuals describe their situation, not on diagnosing or labeling the problem (Rollnick et al., 2008). The supportive and accepting nature of the relationship in MI can be negatively impacted if the worker starts to label, give unsolicited advice, or becomes confrontational.

Conclusion: MI is explicitly consistent with the SBP principle of developing a hopeinducing relationship.

\section{Meaningful Choice}

In strengths-based practice the provision of meaningful choices is central and individuals have the authority to choose (Rapp et al., 2005). Throughout the strengthsbased process the worker is expanding choices and options for the client. The worker helps to clarify choices and encourages the individual to direct the process. The generation of alternatives is a mutual process and individuals are seen as the experts in their own lives (Rapp \& Goscha, 2006). The work in SBP is client-directed. Individuals are encouraged to generate solutions and alternative courses of action (Rapp et al., 2005).

Motivational interviewing supports autonomy and choice (Miller \& Rollnick, 2002). Individuals are empowered to make choices, set the agenda, prioritize their goals, and function independently. Specific skills and tools are utilized to increase an individual's perception of autonomy and control (e.g. Manthey, 2011). Clients are perceived as being the experts in their own lives and are empowered to make choices and provide direction within the interaction. Motivational interviewing helps individuals increase their confidence in their ability to make decisions and changes (Rollnick et al., 2008).

Conclusion: Motivational interviewing is explicitly consistent with the SBP principle of meaningful choice.

\section{Collaboration}

Strengths-based practice assumes that we best serve clients by collaborating with them. Workers who use SBPs approach individuals as collaborators who have specific skills and experiences to offer, while remaining open to the wisdom, experience and knowledge of individuals (Saleebey, 2006). This allows the practitioner to work with 
individuals rather than on them. The individual's voice should be heard and valued throughout all levels and aspects of intervention and practice (Rapp \& Goscha, 2006).

Motivational interviewing assumes that we best serve individuals by collaborating with them. A large part of the spirit of MI includes the collaborative relationship that should be present between the worker and the individual (Miller \& Rollnick, 2002). MI views both the worker and the individual as equally important to the process. If a worker drifts away from being collaborative with an individual (e.g., starts to give unsolicited advice or suggestions, or becomes confrontational) the worker is no longer providing motivational interviewing (Rollnick et al., 2008). Collaboration is considered one of the essential aspects of the relationship that facilitates positive change (Miller \& Rollnick, 2002).

Conclusion: Motivational interviewing is explicitly consistent with the principle of collaboration.

\section{Trials and Opportunity}

Strengths-based practice assumes that trauma, abuse, illness, and struggle may be harmful but they may also be sources of challenge and opportunity (Saleebey, 2006). Often individuals have misperceived SBP as ignoring problems (Rapp \& Goscha, 2006). Instead, SBP focuses on aspects of humanity that indicate that despite adversity individuals are often resilient and resourceful (Saleebey, 2000). Workers acknowledge problems and struggles; however the workers' focus is to explore and learn from individuals' strategies to overcome traumatic and adverse events (Saleebey, 2006).

Motivational interviewing is focused on helping people mobilize commitment to change despite historical problems (Miller \& Rollnick, 2002). MI is primarily present and future focused. The past informs why someone wants to change and may be used to help build self-efficacy, but it is not the focus of the work with the client (Miller \& Rollnick, 2002). MI attempts to clarify current and future objectives and develop discrepancy between current behavior and important goals (Rollnick et al., 2008). In a way similar to SBP, MI respects an individual's wisdom gained through prior experience and draws on that wisdom to explore why the individual might consider behavioral change.

Conclusion: Motivational interviewing is explicitly consistent with the SBP principle that trials can also be sources of opportunity.

\section{Change/Growth Potential}

Strengths-based practice assumes that the worker does not know the upper limits of individuals' capacity to grow and change (Saleebey, 2006). Serious consideration is given to individual, group, and community aspirations (Rapp \& Goscha, 2006). Individuals often feel bound by past experiences, assessments, diagnoses, or judicial sentences. By purposefully avoiding labels and by having high expectations, workers empower individuals to believe in their own capacity to obtain their goals (Rapp \& Goscha, 2006). This is accomplished through keeping a close alliance with the individual's hopes, values, and aspirations (Saleebey, 2006). 
Motivational interviewing assumes that individuals truly can change and achieve their goals (Miller \& Rollnick, 2002). These goals are often extensively explored in order to increase motivation for change (e.g Corrigan et al., 2001). The worker values and closely aligns with individuals' long term goals. The worker's belief in a person's capacity to change is considered fundamental in the practice of supporting self-efficacy (Rollnick et al., 2008). Beyond the underlying assumptions of MI, there is a skill base for increasing individuals' belief in their capacity for change (Miller \& Rollnick, 2002). MI selectively reinforces language that reflects the person's desires, abilities, reasons, and needs for change (e.g. Amrhein, Miller, Yahne, Palmer, \& Fulcher, 2003).

Conclusion: Motivational interviewing is explicitly consistent with the principle that the worker does not know the upper limits of an individual's capacity to grow and change.

\section{Areas of Divergence}

Based on this systematic comparison it was determined that MI is either explicitly or philosophically consistent with the primary principles of SBP (See Table 1). While the "not consistent" category was not appropriate to be used in comparing MI to the principles of SBP, there were several areas of nuanced divergence also noted. For instance, MI does not express a particular preference between naturally occurring vs. formal resource use (e.g. governmental programs), while SBP contains a preference towards using naturally occurring resources (e.g. neighbors, friends or community groups) (Rapp \& Goscha, 2006).

In addition, MI may or may not include a problem focus depending on the context. MI may avoid a problem focus in situations where it is being used to resolve ambivalence and increase motivation to obtain a specific pro-social goal, such as resolving ambivalence regarding obtaining a job (e.g., Larson, 2008) or attempting education (e.g. Manthey, 2011). In other situations MI attempts to develop discrepancy between current problem behaviors and an individual's long term goals. These include situations such as substance abuse (Miller \& Rollnick, 2002) or child abuse and neglect (Forrester, McCambridge, Waissbein, Emlyn-Jones, \& Rollnick, 2008). For example, an individual may have a desire to be a good parent but finds that drug addiction becomes a barrier to accomplishing that goal. It should be noted that MI does not blame, label, or diagnose people (which would also be contrary to SBP). Instead, MI attempts to help an individual change behavior toward being more consistent with the individual's long term goals and values.

Another area of nuanced divergence may be in the domain of concrete resource acquisition. As described earlier, a major component of SBP is its emphasis on pragmatically using current resources, talents, and skills to form a plan for goal attainment. Linking and using strengths for goal attainment moves well beyond simply knowing about or recognizing strengths, it is at the heart creative social work practice. Where claims about SPB sometimes go awry is when practitioners only become familiar with strengths and do not actually utilize them in action. Motivational interviewing does 
more than just devote some attention to strengths. For instance, MI includes both goal planning and action step components that are related to strengths such as desires and

\section{Table 1: Depiction of the Consistency of Motivational Interviewing with} Strengths-based Practice.

\begin{tabular}{|c|c|c|}
\hline Strengths Principles & Explicitly Consistent* & Philosophically Consistent* \\
\hline $\begin{array}{l}\text { 1. Strengths based practice is goal } \\
\text { oriented }\end{array}$ & $\begin{array}{l}\text { MI is focused on goals and values } \\
\text { exploration. }\end{array}$ & \\
\hline $\begin{array}{l}\text { 2. Strengths-Based practice contains a } \\
\text { systematic means of assessing } \\
\text { strengths }\end{array}$ & & $\begin{array}{l}\text { MI provides skills to assess } \\
\text { individuals' own confidence in their } \\
\text { ability to make change. Affirmation } \\
\text { skills are used to reinforce strengths. }\end{array}$ \\
\hline $\begin{array}{l}\text { 3A: Strengths-Based practice sees the } \\
\text { environment as rich in resources }\end{array}$ & & $\begin{array}{l}\text { MI assumes individuals know their } \\
\text { environment and its resources better } \\
\text { than anyone else. Plans for change may } \\
\text { or may not include naturally occurring } \\
\text { resources. }\end{array}$ \\
\hline $\begin{array}{l}\text { 3B: In strengths-based practice } \\
\text { explicit methods are used for using } \\
\text { client and environmental strengths for } \\
\text { goal attainment }\end{array}$ & & $\begin{array}{l}\text { Although explicit methods are not } \\
\text { always used, MI assumes that every } \\
\text { individual group or family has } \\
\text { strengths. The worker affirms personal } \\
\text { and environmental strengths which can } \\
\text { be used for goal attainment. The } \\
\text { worker uses affirmation of strengths for } \\
\text { the purpose of building self-efficacy. }\end{array}$ \\
\hline $\begin{array}{l}\text { 4. The strengths-based relationship is } \\
\text { hope-inducing }\end{array}$ & $\begin{array}{l}\text { The MI relationship facilitates hope, } \\
\text { confidence and motivation for } \\
\text { change. }\end{array}$ & \\
\hline $\begin{array}{l}\text { 5. In strengths-based practice the } \\
\text { provision of meaningful choices is } \\
\text { central and individuals have the } \\
\text { authority to choose }\end{array}$ & $\begin{array}{l}\text { MI supports autonomy, choice and } \\
\text { personal control. }\end{array}$ & \\
\hline $\begin{array}{l}\text { 6. Strengths-based practice assumes } \\
\text { that we best serve clients by } \\
\text { collaborating with them }\end{array}$ & $\begin{array}{l}\text { Collaboration is considered one of } \\
\text { the essential aspects of the MI } \\
\text { relationship that facilitates change. }\end{array}$ & \\
\hline $\begin{array}{l}\text { 7. Strengths-based practice assumes } \\
\text { trauma and abuse, illness and } \\
\text { struggle, may be injurious but they } \\
\text { may also be sources of challenge and } \\
\text { opportunity }\end{array}$ & $\begin{array}{l}\text { MI is focused on helping people } \\
\text { mobilize commitment to change } \\
\text { despite historical problems. MI is } \\
\text { primarily present and future } \\
\text { focused, the past is informative but } \\
\text { it is not the focus of the } \\
\text { intervention. }\end{array}$ & \\
\hline $\begin{array}{l}\text { 8. Strengths-based practice assumes } \\
\text { that the worker does not know the } \\
\text { upper limits of individuals' capacity } \\
\text { to grow and change }\end{array}$ & $\begin{array}{l}\text { Belief that individuals truly can } \\
\text { change and achieve their goals is } \\
\text { considered basic to MI and clinical } \\
\text { skills are developed meant to } \\
\text { increase clients' belief in their } \\
\text { capacity for change. }\end{array}$ & \\
\hline
\end{tabular}


abilities. However, MI does not go as far as other practices, such as Strengths-based Case Management (Rapp \& Goscha, 2006) which assists clients in developing very detailed strengths assessments and utilitarian goal attainment plans. These plans are then revisited repeatedly to help increase the likelihood that goals are met. While there is a lot of overlap between SBP and MI in this area there is also difference. The difference may be present because MI has a greater focus on building motivation while SBP's such as SBCM have a greater focus on planning and action. Therefore, because of their divergent foci, SBPs such as SBCM and interventions like MI may benefit each other.

Finally, MI is described as a way of being with people (Miller \& Rollnick, 2002) and is primarily used as a tool or intervention to address behavior change issues. It is a means for achieving positive behavior change ends. In other words, SBP provides an overarching perspective (Saleebey, 2006) while MI is an approach that may not be appropriate for every situation (Miller \& Rollnick, 2009). Therefore, when workers are highly trained in MI they learn to smoothly move in and out of the MI intervention as needed (Miller \& Moyers, 2006). In contrast, because of its overarching perspective, it has been contended that SBP may be appropriate for any human service interaction (Saleebey, 2006).

As discussed previously, SBP does not ignore barriers to goal attainment, but rather focuses on what is working well, coping strategies already developed, and on hopes for the future. MI may provide individuals who use SBP with skills to navigate situations where individuals want to change behaviors that get in the way of their long-term goals and desires.

\section{A GOOD FIT FOR SOCIAL WORK}

Research on SBP and MI suggest that there may be a potential useful alignment between the two approaches. We begin this section by reviewing empirical support for SBP and MI. We then discuss ways in which they may be used in conjunction. We conclude this section with a case-scenario which illustrates the potential reciprocal relationship between MI and SBP.

\section{Empirical Support for Strengths-based Practice}

Strengths-based work is most explicitly articulated in case management practice (e.g. Rapp \& Goscha, 2006); otherwise the notion of SBP is predicated on a set of values and principles. This conceptualization of SBP as an overarching perspective has garnered critique from researchers (e.g., Staudt et al., 2001) who contend that it is difficult to assess a direct relationship between SBP and outcomes (for a detailed discussion on this topic see Probst, 2009). Despite this critique, there are several areas which show promise. The primary SBP research has been conducted on SBCM. Four experimental, three quasiexperimental, and three non-experimental design studies have been conducted on SBCM which show positive results (Barry, Zeber, Blow, \& Valenstein, 2003; Bjorkman, Hansson, \& Sandlund, 2002; Kisthardt, 1994; Macias, Farley, Jackson, \& Kinney, 1997; Macias, Kinney, Farley, Jackson, \& Vos, 1994; Modcrin, Rapp, \& Poertner, 1988; Rapp \& Chamberlain, 1985; Rapp \& Wintersteen, 1989; Ryan, Sherman, \& Judd, 1994; 
Stanard, 1999). In addition, implementation of SBP has been attempted in a variety of fields such as substance abuse (Brun \& Rapp, 2001; Redko, Rapp, Elms, Snyder, \& Carlson, 2007), school counseling (Saleebey, 2008), gerontology (Sullivan \& Fisher, 2004; Whitley, White, Kelley, \& Yorke, 1999), corrections (Clark, 1997; Leukefeld et al., 2003), and at-risk youth (Arnold, Walsh, Oldham, \& Rapp, 2007; Werrbach, 1996). There are also hundreds of conceptual or theoretical articles describing potential applications of SBP to a variety of populations and circumstances.

Further support comes from secondary sources. For instance, similar to the efforts presented in this article, Rapp et al. (2005) systematically compared several intervention models to the tenets of SBP and proclaimed them strengths-based. These models include asset building, solution-focused therapy and supported employment (Rapp et al. 2005). Each of these related models have been studied in their own right, the results of which provide secondary support for SBP. For example, see Kim's (2008) meta-analysis on solution-focused therapy. SBP is further supported by complementary research in other fields such as resiliency, positive psychology, and common change factors research (Norman, 2000; Saleebey, 2006).

\section{Empirical Support for Motivational Interviewing}

MI has a very large evidence-base including over 200 empirical studies and over five meta-analyses showing positive outcomes (Wagner \& Conners, 2010). A meta-analysis can take studies conducted in a variety of situations and with a variety of populations and combine the results to determine if there is a significant effect across studies, rather than just in isolated instances. An important meta-analysis conducted by Hettema, Steele, \& Miller, (2005) found that MI has an additive effect when combined with other interventions. The additive effect found by Hettema et al. shows an increased length of intervention potency for individuals who receive a combined intervention approach across a variety of MI and other intervention combinations. In other words, it was found that when MI is combined with other interventions it may increase the effectiveness of both MI and the other approach. For instance, it may be that intervention models based on SBP (such as SBCM) may become more effective when used in combination with MI than either intervention might be when used alone. The additive effect finding lends weight to the contention that MI and SBP may be a good fit. For example, it may be easier to implement and learn MI skills if the overarching system that supports the worker functions from a strengths perspective. It may also be of benefit for workers who use SBPs to build skills that increase hope and motivation within their clients.

\section{A Combined Approach}

There is some initial support for a combined SBP-MI intervention approach in the literature. While there are methodological weaknesses, some studies have shown a potential positive linkage between motivational interviewing and strengths-based work. One study, which focused on using MI to improve treatment entry for substance misusing adolescents, audio-taped and coded 54 sessions of workers utilizing the StrengthsOriented Referral for Teens (SORT) (Smith \& Hall, 2007; Smith, Hall, Jang \& Arndt, 2009). They found that when the worker had higher adherence to SORT there was greater 
use of MI, a greater discussion of client strengths, and more utilization of solutionfocused language. Another study which was designed to help offenders obtain employment had 500 drug court participants take part in MI and SBCM as pieces of an overall vocational intervention (Leukefeld et al., 2003). The participants reported increased confidence and increased feelings of capability of finding employment or obtaining education.

In addition, SBP may inform the worker trained in MI on how best to work with strengths during an action stage. SBP would provide workers trained in MI the ability to smoothly transition from MI skills into strengths-based skills appropriately matched to the individual's readiness. SBP would complement MI as the individual receiving services moves into action planning. For instance, a large part of SBP is linking resources and strengths to a specific goal and creating initial tasks. Sometimes an individual may be reluctant to pursue a strengths-based action plan because of low confidence. If this is the case, the worker's ability to drop back and use MI skills which focus on building confidence may be beneficial. Conversely, if a worker is using MI and a client becomes very motivated to change and is ready to develop an action plan, having that plan grounded in client strengths in a detailed and methodical fashion will likely increase success.

Both MI and SBP support personal empowerment and hold the belief that the individuals already have the skills necessary to solve their problems and achieve their goals. Motivational interviewing and SBP place emphasis on the relationship as foundational to the change process and hold the belief that engendering hope is essential. SBP and MI do not expect workers to be experts in charge of how an individual changes. Instead, both approaches enable the worker to become skilled at facilitating a process of exploring and reinforcing the client's own goals, values, and strengths. MI may be an important aspect of strengths-based practice, particularly as one goes about conducting an assessment and then helping the individual hone in on a goal or set of goals important to him or her.

Concluding this section is a case-example which illustrates how SBP and MI may be used together. However, prior to the case-scenario it is helpful to note some of the microskills which are used in MI: (1) open-ended questions, (2) affirmations, (3) reflections and (4) summary statements. These micro skills are used to elicit change talk, in other words, desires, abilities, reasons, or needs for change (Miller \& Rollnick, 2002). One of the unique characteristics of MI is that it is designed to elicit change talk rather than simply waiting for it to occur. This practice is similar to a worker listening for and affirming strengths. Miller and Rollnick (2002) have described many methods for eliciting change talk, including asking questions which often lead to answers containing change talk (e.g., In what ways might change be a good thing?) and avoiding questions which are likely to lead to resistance (e.g., Why haven't you changed?). When change talk is elicited, the worker may use reflection, affirmation, or requests for elaboration to elicit further change talk.

The fundamental principles of motivational interviewing include: rolling with resistance rather than confronting it, expressing empathy for individuals' experiences, 
developing discrepancy between where they currently find themselves and their long term goals and values, and supporting their self-efficacy (Miller \& Rollnick, 2002). The fundamental principles of MI are supported through learning the behavioral micro skills.

\section{Case-example}

Julie is a mother of two who has been diagnosed with a psychiatric disability, has had history with the child welfare system, and has had difficulties with substance use. Her children are aged two and five and are currently staying with Julie's older sister. Julie is currently unemployed; however, she receives $\$ 570$ a month in SSI. She rents a basement apartment from a long-term friend familiar with her situation. Julie receives case-management services at her local community mental health center. Her casemanager is assisting her in filling out a strengths assessment. The strengths assessment includes three domains: (1) current strengths (2) individual desires/aspirations, and (3) past resources. These three domains are present across seven categories: (1) home/daily living, (2) assets/financial/insurance, (3) employment, education/specialized knowledge, (4) supportive relationships, (5) wellness/health, (6) leisure/recreation, and (7) spirituality/culture.

The purpose of the strengths assessment is to identify personal goals through exploration of the desires and aspirations domain, these goals are then linked with the current strengths and past resources domains (Rapp \& Goscha, 2006). The eventual aim is to utilize the identified strengths and resources for goal attainment. The following transcript picks up after initial greetings are made and the strengths assessment is beginning to be filled out.

Worker: To start out Julie, what would you like to see differently in your living situation? (Open question)

Julie: I don't know. I like where I live, Nick's known me a long time and understands me and my situation. I don't think someone else would be as understanding.

Worker: Having a landlord that understands what it's like to have a psychiatric disability is important to you. (Reflection)

Julie: Yeah, he's been a friend of my family for years, he knows my sister and my mom, and understands when things aren't going well. I don't think I'd get that kind of leeway if I rented an apartment from someone else.

Worker: So one of your strengths is having a relationship with Nick who helps you out with housing and other things when you need him to. (Reflection)

Julie: Yes! He and Mary even used to babysit for me sometimes when I still had my kids. He really is a nice guy.

Worker: He's a good friend and you've really maintained a positive relationship with him. (Affirmation)

Julie: Yeah 
Worker: So things are going pretty good and you don't really have a goal for changing your housing or your living situation right now. (Reflection).

Julie: I guess for my housing. But I really want my kids back. They live with my sister because supposedly I can't take care of them. Which I don't think is true. Stupid social workers taking away my kids! These people don't have a clue what it's like to be me. I'm a good parent!

Worker: So your kids were taken away and you think you're a good mom and you want them to live with you. (Reflection)

Julie: Yeah! What else do you think I want? I'm a mom! I love my kids.

Worker: It's a natural drive for mothers to want to take care of and be with their kids. (Reflection).

Julie: Yeah. It is.

Worker: What would it be like if you had your kids back living with you? (Open question) (Writes "I would like to gain custody of my kids" in the individual desires, aspirations domain of the daily living category on the strengths assessment).

Julie: It would be awesome! I wouldn't have to visit them at my sister's and we could be alone together. Last time I got my kids back I tucked them into bed every night and sang songs to them. I was a good mom. I took them to the park all the time and I made really good meals, not like when I'm living alone and only cook for myself.

Worker: You've taken care of them most of their lives and you've been successful at getting your kids back before. (Reflection)

Julie: Yes.

Worker: What was it that happened that made it possible for you to get your kids last time? (Open Question)

Julie: Well the main thing was that I was clean and sober. That's really what the court wanted me to do. When I'm not using my kids are able to stay with me.

Worker: So the biggest barrier to you achieving the goal of having custody of your kids is drug use. (Reflection)

Julie: Yes, they told me that as long as I was using I couldn't keep my kids.

Worker: And you really want your kids back because being a mother is a big part of who you are as a person, you love your kids, and you think you would be a good at taking care of your kids. (Reflection)

Julie: Yeah, I would be good at taking care of my kids. No one else should parent my kids. I'm a good mom.

Worker: Having your kids live with you would be the best thing for your kids. (Reflection). 
Julies: Yes! They tell me they want to come back and live with me and they miss me so much. I love my sister, but she isn't their mother. I am their mother and I know them best and how to take care of them best.

Worker: What else did you do that made you feel like you were successful at being a parent. (Open Question)

Julie: Well, everything wasn't always great, sometimes things were hard. But we always got by. I never hit my kids, and I always told them I loved them. We might not be perfect but we've always been a close family.

Worker: Good for you! It can be hard not to take out your frustrations on others when things are hard, but you try really hard not to do that to your kids. (Affirmation and Reflection)

Julie: Yeah, I do try really hard not to do that.

Worker: That's important to you. (Reflection)

Julie: Yes it is.

Worker: And you're a close family. (Reflection)

Julie: Yeah, like when we watch TV together, we all cuddle together in a big group. I know some families who can't stand being in the same room together, but we like to cuddle and talk and watch TV. It used to be my favorite time of the day.

Worker: You love your kids a lot and they love you. (Reflection)

Julie: I miss them so much.

Worker: So one thing you are considering is attempting to stay sober so that you can get your kids back. And you've done it before so you think you'll be able to do it again. (Reflection)

Julie: Yep, that's what I'm going to try to do.

Worker: And you have a lot of strengths that might help you with that goal, such as your past success as a parent, some skills you've developed that help you deal with frustration, and maybe even having stable housing with your friend Nick. (Summary)

Julie: I guess I do.

Note that the worker used the open-ended questions strategically to elicit strengths and then affirmed them. Even though the initial topic was ultimately about a selfidentified problem (Julie having her kids taken away) the problem was also a positive life goal about being a good parent. The strength of desiring to be a good parent may even drive other positive changes in the future (such as obtaining a job or obtaining an education in order to better provide for her children). Just as Saleebey (2004) and Weick, Kreider, and Chamberlain (2006) point out, often one has to start out with a problem and then listen carefully for desires, talents, resources, and other strengths that may be glimmering in the background. The worker was careful to listen for the strengths that were in Julie's story and sometimes reframed perceived problems as strengths. 
The worker also elicited change talk such as Julie's past successes and her desires to have her kids back. In some cases the worker elicited strengths and change talk that were the same, such as when Julie discussed her ability to avoid taking out her frustrations on her kids and other positive parenting skills. The worker strategically used reflections and open questions to obtain these types of responses rather than focusing on deficits or diagnoses or asking questions that might engender resistance. Motivational interviewing as with SBP breaks ties with the past and changes to focus on a future beyond the problem (Miller \& Rollnick, 2002; Weick et al., 2006).

In this scenario the worker, together with Julie, filled out the rest of the strengths assessment. They discussed many topics during a relatively short period of time in order to get a snapshot of what Julie's ultimate goals and desires were. However, as with all SBPs it is intended that the strengths assessment will be an ongoing and dynamic process over time. Together, Julie and the worker also identified strengths and resources. The following is Julie's sample strengths assessment (format and content adapted from Rapp \& Goscha, 2006).

Table 2: Julie's Strength's Assessment

\begin{tabular}{|c|c|c|}
\hline $\begin{array}{l}\text { Current Strengths: } \\
\text { What are my current strengths? (i.e. } \\
\text { talents, skills, personal and } \\
\text { environmental strengths)? }\end{array}$ & $\begin{array}{l}\text { Individual's Desires, } \\
\text { Aspirations: } \\
\text { What do I want in my life? }\end{array}$ & $\begin{array}{l}\text { Past Resources - Personal, } \\
\text { Social, \& Environmental: } \\
\text { What strengths have I used in } \\
\text { the past? }\end{array}$ \\
\hline \multicolumn{3}{|c|}{ Home/Daily Living } \\
\hline $\begin{array}{l}\text { - Rents basement apartment } \\
\text { - Good relationship with landlord Nick } \\
\text { - Have most of the physical things I need } \\
\text { (furniture, cooking utensils etc.) } \\
\text { - Has good parenting skills }\end{array}$ & $\begin{array}{l}\text { "I want to gain custody of my kids” } \\
\text { “I’d like a computer or laptop” }\end{array}$ & $\begin{array}{l}\text {-Was able to gain custody of } \\
\text { kids last year. } \\
\text { - Knows a guy that can get } \\
\text { electronics at a discount }\end{array}$ \\
\hline \multicolumn{3}{|c|}{ Assets - Financial/Insurance } \\
\hline $\begin{array}{l}\text { - Currently receives } \$ 570 \text { in SSI } \\
\text { - Has Medicaid } \\
\text { - Receives food stamps }\end{array}$ & $\begin{array}{l}\text { "I want to earn more money so I have } \\
\text { the freedom to do more things and get } \\
\text { a computer" }\end{array}$ & $\begin{array}{l}\text { - I pay most of my bills on my } \\
\text { own and on time. }\end{array}$ \\
\hline \multicolumn{3}{|c|}{ Employment/Education/Specialized Knowledge } \\
\hline $\begin{array}{l}\text { Knowledgeable and skilled with the } \\
\text { food industry } \\
\text { "I am learning more and more about } \\
\text { recovery all the time" }\end{array}$ & $\begin{array}{l}\text { "I want to get a job where I get to } \\
\text { cook things I like" } \\
\text { "I might want to get a chef or other } \\
\text { cooking certification" } \\
\text { "I think I would be a good peer } \\
\text { support worker" }\end{array}$ & $\begin{array}{l}\text { - Has worked in several fast food } \\
\text { positions, and once as a waitress. } \\
\text { - Graduated from high school }\end{array}$ \\
\hline
\end{tabular}




\begin{tabular}{|c|c|c|}
\hline \multicolumn{3}{|c|}{ Supportive Relationships } \\
\hline $\begin{array}{l}\text { - Sister (Megan) listens to me and cares } \\
\text { for my kids } \\
\text { - Mom (Susan) take me places when I } \\
\text { can’t get there by bus } \\
\text { - Nick (Landlord) has known me a long } \\
\text { time and tries to understand me } \\
\text { - Neighbor (Fran) used to watch my kids } \\
\text { sometimes and very friendly } \\
\text { - Rose (Case Manager) helped me } \\
\text { believe in myself and learn about } \\
\text { recovery }\end{array}$ & "I would like to have more friends" & $\begin{array}{l}\text {-“I have always been close with } \\
\text { my mom and sister" } \\
\text { - Ex-boyfriend (Bob) used to be } \\
\text { a good support ("He made me } \\
\text { feel good inside”) } \\
\text { - Stewart (Children's Father) } \\
\text { used to be a good financial } \\
\text { support for a while. }\end{array}$ \\
\hline \multicolumn{3}{|c|}{ Wellness/Health } \\
\hline $\begin{array}{l}\text { - Lamictal helps with my mood “I don’t } \\
\text { feel suicidal as much” } \\
\text {-“Talking to others about how I’m } \\
\text { feeling helps” } \\
\text {-“I have started exercising when my } \\
\text { sister lets me borrow her pool pass” }\end{array}$ & $\begin{array}{l}\text { "I want to continue to be healthy and } \\
\text { stay in recovery" }\end{array}$ & $\begin{array}{l}\text { "Going out and doing things } \\
\text { made me feel better about } \\
\text { myself” (e.g. movies, dancing, } \\
\text { shopping, etc.) }\end{array}$ \\
\hline \multicolumn{3}{|c|}{ Leisure / Recreational } \\
\hline $\begin{array}{l}\text { - Enjoys music (Salsa and Swing) and } \\
\text { dancing (Swing) } \\
\text { - "I like watching murder mysteries and } \\
\text { other TV shows, especially with my } \\
\text { family" }\end{array}$ & $\begin{array}{l}\text { "I want to make more friends and } \\
\text { spend time with them" }\end{array}$ & $\begin{array}{l}\text { - used be involved with the high } \\
\text { school dance club. } \\
\text { - went out for track in high } \\
\text { school } \\
\text { - used to love to swim }\end{array}$ \\
\hline \multicolumn{3}{|c|}{ Spirituality/Culture } \\
\hline $\begin{array}{l}\text {-“God has been with me even when } \\
\text { everyone else wasn't” }\end{array}$ & $\begin{array}{l}\text { "I would like to find a church where I } \\
\text { feel accepted for who I am" }\end{array}$ & $\begin{array}{l}\text {-“Going to Church on Sunday } \\
\text { and going to bible study on } \\
\text { Wednesdays was important in } \\
\text { my childhood” }\end{array}$ \\
\hline
\end{tabular}

After the strengths assessment is completed, the worker attempts to help Julie prioritize which goals she would like to work on.

Worker: We've talked about quite a few things today, Julie. Is it okay if I talk with you a little bit about what others have found helpful in similar situations? (Closed Question - Asking Permission)

Julie: Sure

Worker: A lot of people find that they don't need help with all of the goals that they put on the strengths assessment. Many people just want help with a few big things and then they attempt to achieve other goals on their own or at a later time. For some 
it's also been easier to attempt only a few goals at a time so that they don't get pulled in too many directions at once. But that's really up to you. You have lots of options. What do you think? (Giving Information and Open Question)

Julie: This sounds fine to me. I don't really need help finding a new church anyway. I can do that on my own.

Worker: So what are the top two or three goals that we've discussed today that you might like my help with? (Closed Question)

Julie: I definitely want to get my kids back. They're the most important people in my life. I also need help getting a job as a cook or chef or something...but not waitressing, I want to cook, not work tables or the register. Those are the two biggest things. I might also like a computer, but I can't afford one right now.

Worker: So managing your sobriety so that you can get your kids back and getting a job as a cook so that you can do more things and perhaps get a computer really top your list. (Reflection).

\section{Julie: Yep!}

In this section the worker was careful to not give unsolicited advice, but instead consciously chose to instill autonomy and choice throughout the process. The worker helped Julie to prioritize and set the agenda for their future work. From here the worker can: (1) help Julie to link strengths (e.g. desires, resources, abilities, and skills) to a practical plan for goal attainment, as well as move into motivational interviewing and elicit change talk when needed (e.g. desires, abilities, reasons and needs for change) in order to increase motivation, confidence and hope.

\section{IMPLICATIONS FOR SOCIAL WORK}

Based on our systematic comparison we contend that MI and SBP are highly compatible. Given the wide use of SBP, implications from this analysis include that MI may be of benefit for social work agencies, researchers, educational institutions, and practitioners. These implications are detailed in the following subsections.

\section{Social Work Agencies}

Agencies who want to more closely operate from a SB approach may benefit from motivational interviewing skillset acquisition which may augment their SB efforts. If agencies struggle to determine hands on skill development that include strengths-based elements and is evidence-based, they may turn to MI. It is also recommended that systemic barriers to implementation of MI (such as programs that emphasize external motivators, confrontation, and problem focus) may find that those barriers are overcome if they develop an overarching strengths-vision and culture. As described previously a combined MI-SBP approach may have the potential of sustaining good outcomes longer (e.g. Hettema et al., 2005). Agencies that report that they frequently have issues with client "compliance" may want to consider utilizing a combined MI-SBP approach to reduce adversarial interactions between staff and participants. Programs that find that 
they sometimes sacrifice long term behavior change for short term compliance may also want to use this approach.

\section{Social Work Research}

Social work has distinguished itself from other helping professions through its focus on facilitating change (Fraser, 2004) and, at its most basic element, research in the social work field entails the study of intervention and the development of systematic change strategies (Fraser, 2004; Thyer, 2007). Motivational interviewing is an intervention geared toward helping individuals talk themselves into behavior change. Strengths-based practice is meant to envision, explore and assist individuals in achieving their goals. Both approaches are not only compatible with each other but are consistent with this important fundamental aspect of social work research.

We echo the Rapp et al. (2005) recommendation that researchers who wish to contend that a given intervention is strengths-based conduct a systematic analysis in order to support such an assertion. The eight domains used here may be beneficial for researchers who wish to conduct a similar comparison of other interventions.

The additive effect of MI (Hettema et al., 2005) described previously is intriguing and lends support for further research aimed at measuring the outcomes of a combined MI-SBP approach. Researchers may use this analysis as a launching point for future studies. In addition, further analyses and research into each of the above eight domains would benefit both MI and SBP researchers as they attempt to refine their approaches.

\section{Social Work Education}

Schools of social welfare may want to include MI in their curriculum as is currently the case in schools such as Portland State University, University of Utah, and Eastern Washington University, among others. Some social work professors have suggested that MI may fit well within HBSE coursework (van Wormer, 2007) while others have suggested that MI could play a larger role in social work practice and education (Hohman, 2011; Wahab, 2005).

It is important for social work educators to be able to measure a student's competency when teaching skills-based interventions. While there is an instrument available that measures an agency's fidelity to SBCM (Rapp \& Goscha, 2006) there are no instruments which measure an individual worker's skills or competence at providing SBP. In contrast, there are several different instruments which can be used to measure a student or worker's ability to provide MI. For example, the Motivational Interviewing Skills Code (MISC) (Miller, Moyers, Ernst, \& Amrheim, 2003) and the Motivational Interviewing Treatment Integrity manual (MITI) (Moyers, Martin, Manuel, Miller, \& Ernst, 2007) provide valuable information about the degree to which an individual provides practice which is adherent to MI. If schools were to utilize such instruments not only would they be able to contend that they teach content on SBP but that students graduate with a demonstrable ability to utilize a practice that contains SB elements. 
Teaching SBP content is a requirement for reaccreditation by the Council on Social Work Education (CSWE) and the infusion of SBP into social work BSW and MSW programs has been a central theme for many schools of social work (Cox, 2001; Donaldson, Early, \& Wang, 2009). In addition, the recent move away from content-based school accreditation toward competence-based school accreditation by CSWE means that a practical means of measuring whether a practitioner is delivering SBP needs to be developed. Until this occurs, adding MI into practice coursework or adding a standalone MI class may be beneficial.

\section{Social Work Practitioners}

Identifying and affirming strengths is key to the value stance of the social work profession (Wilson, 2006); therefore, using SBP and MI may provide an effective practice approach for professionals who find the values consistent with their personal practice vision. Using interventions that are consistent with social work values and ethical principles is an important additional criterion workers should use when selecting an approach. MI is consistent with SBP and is also consistent with other principles and values described in the NASW code of ethics such as self-determination.

Using an MI-SBP approach may help both the worker and the client feel less tension within the helping relationship. A combined approach may also help the worker develop skills to more easily align with client goals. Social work practitioners are progressively becoming burdened by increasing case load sizes and other demands. MI has been recommended as a possible means for professionals to reflexively assess their own practice in order to potentially prevent burnout and avoid compassion fatigue (Parks, 2007). Therefore, using an MI-SBP approach may not only reduce tension in the helping relationship but reduce tension for the worker in other ways through reflective practice. Most importantly, using an MI-SBP approach may increase the likelihood that clients will achieve lasting behavior change and goal attainment.

\section{References}

Amrhein, P. C., Miller, W. R., Yahne, C. E., Palmer, M., \& Fulcher, L. (2003). Client commitment language during motivational interviewing predicts drug use outcomes. Journal of Consulting and Clinical Psychology, 71, 862-878.

Arnold, E. M., Walsh, A. K., Oldham, M. S., \& Rapp, C. A. (2007). Strengths-based case management with high-risk youth. Families in Society, 88(1), 86-94.

Barry, K. L., Zeber, J. E., Blow, F. C., \& Valenstein, M. (2003). Effect of strengths model versus assertive community treatment model on participant outcomes and utilization: Two-year follow-up. Psychiatric Rehabilitation Journal, 26, 268-277.

Bjorkman, T., Hansson, L., \& Sandlund, M. (2002). Outcome of case management based on strengths model compared to standard care. A randomized controlled trial. Social Psychiatry and Psychiatric Epidemiology, 37, 147-152. 
Brun, C., \& Rapp, R. C. (2001). Strengths-based case management: Individuals' perspectives on strengths and case manager relationship. Social Work, 46(3), 278288.

Chung, R. J., Burke, P. J., \& Goodman, E. (2010). Firm foundations: Strengths-based approaches to adolescent chronic disease. Current Opinion in Pediatrics, 22, 389397.

Clark, M. D. (1997). Strength-based practice: A new paradigm. Corrections Today, 59(2), 201-202.

Clark, M. D. (2001). Change-focused youth work: The critical ingredients of positive behavior change. Journal of the Center for Families, Children \& the Courts, 3, 5972.

Clark, M. D. (2005). Motivational interviewing for probation staff: Increasing the readiness to change. Federal Probation, 69(2), 22-28.

Clark, M. D. (2006). Entering the business of behavior change: Motivational interviewing for probation staff. Perspectives: The Journal of American Probation \& Parole Association, 30(1), 38-45.

Corcoran, J. (2005). Building strengths and skills: A collaborative approach to working with clients. New York: Oxford University Press.

Corrigan, P. W., McCracken, S. G., \& Holmes, E. P. (2001). Motivational interviews as goal assessment for persons with psychiatric disability. Community Mental Health Journal, 37(2), 113-122.

Cox, A. L. (2001). BSW students favor strengths/empowerment-based generalist practice. Families in Society, 82(3), 305-313.

Davidson, W. S., \& Rapp, C. A. (1976). Child advocacy in the justice system. Social Work, 21(3), 225-232.

Deegan, P. E. (1990). Spirit breaking: When the helping professions hurt. The Humanistic Psychologist, 18(3), 301-313.

Donaldson, L. P., Early, B. P., \& Wang, M. L. (2009). Toward building a culture of strengths in U.S. MSW programs. Advances in Social Work, 10(2) 211-229.

Forrester, D., McCambridge, J., Waissbein, C., Emlyn-Jones, R., \& Rollnick, S. (2008). Child risk and parental resistance: Can motivational interviewing improve the practice of child and family social workers in working with parental alcohol misuse? British Journal of Social Work, 38, 1302-1319.

Fraser, M. W. (2004). Intervention research in social work: Recent advances and continuing challenges. Research on Social Work Practice, 14, 210-222.

Greene, G. J., Lee, M. Y., \& Hoffpauir, S. (2005). The languages of empowerment and strengths in clinical social work: A constructivist perspective. Families in Society, 86(2), 267-277. 
Hettema, J., Steele, J., \& Miller, W. R. (2005). Motivational interviewing. Annual Review of Clinical Psychology, 1, 91-111.

Hohman, M. (2011). Motivational interviewing in social work practice. New York: Guilford Press.

Kim, J. S. (2008). Examining the effectiveness of solution-focused therapy: A metaanalysis. Research on Social Work Practice, 18(2), 107-116.

Kisthardt, W. E. (1994). The impact of the strengths model of case management from the consumer perspective. In M. Harris \& H. Bergman (Eds.), Case management: Theory and practice, pp. 165-182. Washington, DC: American Psychiatric Association.

Larson, J. E. (2008). User-friendly motivational interviewing and evidence-based supported employment tools for practitioners. Journal of Rehabilitation, 74(4), 1830 .

Leukefeld, C., McDonald, H., Staton, M., Mateyoke-Scrivner, A., Webster, M., Logan, T., \& Garrity, T. (2003). An employment intervention for drug-abusing offenders. Federal Probation, 67, 27-31.

Macias, C., Farley, W. O., Jackson, R., \& Kinney, R. (1997). Case management in the context of capitation financing: An evaluation of the strengths model. Administration and Policy in Mental Health, 24(6), 535-543.

Macias, C., Kinney, R., Farley, W.O., Jackson, R., \& Vos, B. (1994). The role of case management within a community support system: Partnership with psychosocial rehabilitation. Community Mental Health Journal, 30(4), 323-39.

Manthey, T. (2011). Using motivational interviewing to increase retention in supported education. American Journal of Psychiatric Rehabilitation, 14(2), 120-136.

Marty, D., Rapp, C. A., \& Carlson, L. (2001). The experts speak: The critical ingredients of strengths model case management. Psychiatric Rehabilitation Journal, 24(3), 214221.

McMillen, J. C., Morris, L., \& Sherraden, M. (2004). Ending social work’s grudge match: Problems versus strengths. Families in Society, 83(3), 317-325.

Miller, W. R., \& Moyers, T. B. (2006). Eight stages in learning motivational interviewing. Journal of Teaching in the Addictions, 5(1), 3-17.

Miller, W. R., Moyers, T. B., Ernst, D., \& Amrhein, P. (2003) The Motivational Interviewing Skills Code (MISC) Manual (Version 2.0). Albuquerque: University of New Mexico, Center on Alcoholism, Substance Abuse, and Addictions.

Miller, W. R., \& Rollnick, S. (2002). Motivational interviewing: Preparing people for change ( $2^{\text {nd }}$ ed.). New York: Guilford Press.

Miller, W. R., \& Rollnick, S. (2009). Ten things that MI is not. Behavioral and Cognitive Psychotherapy, 37, 129-140. 
Miller, W. R., \& Rose, G. S. (2009). Toward a theory of motivational interviewing. American Psychologist, 64(6), 527-537.

Modcrin, M., Rapp, C., \& Poertner, J. (1988). The evaluation of case management services with the chronically mentally ill. Evaluation and Program Planning, 11, 307-314.

Moyers, T., Martin, T., Manuel, J., Miller, W., \& Ernst, D. (2007). Motivational Interviewing Treatment Integrity 3.0. Albuquerque: University of New Mexico, Center on Alcoholism, Substance Abuse, and Addictions.

NASW. (2006). Code of Ethics. Washington, DC: NASW Press.

Norman, E. (2000). Introduction: The strengths perspective and resiliency enhancement, a natural partnership. In E. Norman (Ed.), Resiliency enhancement: Putting the strengths perspective into social work practice (pp. 1-16). New York: Columbia University Press.

Parks, R. (2007). The importance of reflexive practice within the context of life-long career development for rehabilitation counselors. Australian Journal of Rehabilitation Counselling, 13, 20-31.

Probst, B. (2009). Contextual meanings of the strengths perspective for social work practice in mental health. Families in Society, 90(2), 162-166.

Rapp C. A., \& Chamberlain, R. (1985). Case management services to the chronically mentally ill. Social Work, 30(5), 417-422.

Rapp, C. A., \& Goscha, R. (2006). The strengths model: Case management with people with psychiatric disabilities ( $2^{\text {nd }}$ ed.). New York: Oxford.

Rapp, C. A., Saleebey, D., \& Sullivan, W. P. (2005). The future of strengths-based social work. Advances in Social Work, 6(1), 79-90.

Rapp, C. A., \& Wintersteen, R. (1989). The strengths model of case management: Results from twelve demonstrations. Psychosocial Rehabilitation Journal, 13(1), 23-32.

Rapp, R. C. (2006). Strengths-based case management: Enhancing treatment for persons with substance abuse problems. In D. Saleebey (Ed.), The strengths perspective in social work practice ( $4^{\text {th }}$ ed., pp. 128-147). Boston: Pearson Education, Inc.

Redko, C., Rapp, R. C., Elms, C., Snyder, M., \& Carlson, R. G. (2007). Understanding the working alliance between persons with substance abuse problems and strengthsbased case managers. Journal of Psychoactive Drugs, 39(3) 241-250.

Rollnick, S., Miller, W., \& Butler, C. (2008). Motivational interviewing in health care: Helping patients change behavior. New York: Guilford Press.

Ryan, C. S., Sherman, P. S., \& Judd, C. M. (1994). Accounting for case manager effects in the evaluation of mental health services. Journal of Consulting and Clinical Psychology, 62(5), 965-974. 
Saleebey, D. (1996). The strengths perspective in social work practice: Extensions and cautions. Social Work, 41, 296-305.

Saleebey, D. (2000). Power in the people: Strength and hope. Advances in Social Work, 1(2), 127-136.

Saleebey, D. (2001). The diagnostic strengths manual? Social Work, 46(2), 183-187.

Saleebey, D. (2004). Commentary: Response to "Ending social work's grudge match." Families in Society: The Journal of Contemporary Social Sciences, 85(4), 588-590.

Saleebey, D. (Ed.). (2006). The strengths perspective in social work practice ( $4^{\text {th }} \mathrm{ed}$.). Boston: Pearson Education, Inc.

Saleebey, D. (2008). Commentary on the strengths perspective and potential applications in school counseling. Professional School Counseling, 12(2), 68-75.

Saleebey, D. (2010). The strengths perspective. Strengths Institute, University of Kansas School of Social Welfare. Retrieved from: http://www.socwel.ku.edu/strengths/about/index.shtml

Smith, D. S., \& Hall, J. A. (2007). Strengths-oriented referrals for teens (SORT): Giving balanced feedback to teens and families. Health and Social Work, 32(1), 69-72.

Smith, D. S., Hall, J. A., Jang, M., \& Arndt, S. (2009). Therapist adherence to a motivational interviewing intervention improves treatment entry for substance misusing adolescents with low problem perception. Journal of Studies on Alcohol and Drugs,70, 101-105.

Stanard, R. P. (1999). The effect of training in a strengths model of case management on client outcomes in a community mental health center. Community Mental Health Journal, 35(2), 169-179.

Staudt, M., Howard, M. O., \& Drake, B. (2001). The operationalization, implementation, and effectiveness of the strengths perspective: A review of empirical studies. Journal of Social Service Research, 27(3), 1-21.

Sullivan, W. P., \& Fisher, B. J. (1994) Intervening for success: Strengths-based case management and successful aging. Journal of Gerontological Social Work, 22(1.2), 61-74.

Thyer, B. A. (2007). Social work education and clinical learning: Towards evidencebased practice? Clinical Social Work Journal. 35, 25-32.

Tilsen, J., \& Nylund, D. (2008). Psychotherapy research, the recovery movement and practice-based evidence in psychiatric rehabilitation. Journal of Social Work in Disability and Rehabilitation, 7(3/4), 340-354.

van Wormer, K. (2007). Motivational interviewing: A theoretical framework for the study of human behavior and the social environment. Advances in Social Work, 8(1), 19-29. 
van Wormer, K., \& Davis, D.R. (2008). Addiction treatment: A strengths perspective. ( $2^{\text {nd }}$ ed.). Belmont, CA: Brooks/Cole.

Wagner, C., \& Conners, W. (2010). Motivational interviewing: Motivational interviewing bibliography 1983-2007. Mid-Atlantic Addiction Technology Transfer Center. Retrieved from http://motivationalinterview.org/library/biblio.html

Wahab, S. (2005). Motivational interviewing and social work practice. Journal of Social Work, 5(1), 45-60.

Weick, A., Kreider, J., \& Chamberlain, R. (2006). Solving problems from a strengths perspective. In D. Saleebey (Ed.), The strengths perspective in social work practice ( $4^{\text {th }}$ ed., pp. 116-127). Boston: Pearson Education.

Weick, A., Rapp, C., \& Sullivan, P. (1989). A strengths perspective for social work practice. Social Work, 34, 350-354.

Werrbach, G. B. (1996). Family-strengths-based intensive child case management. Families in Society: The Journal of Contemporary Human Services, 77, 216-226.

Whitley, D. M., White, K. R., Kelley, S. J., \& Yorke, B. (1999). Strengths-based case management: The application to grandparents raising children. Families in Society, 80(2), 110-119.

Wilson, S. Z. (2006). Field education: Linking self-efficacy theory and the strengths perspective. The Journal of Baccalaureate Social Work, 12(1), 261-274.

\section{Author note:}

Address correspondence to: Trevor Jay Manthey, 3 Twente Hall, Lawrence, KS 66044.

Email: trevormanthey@gmail.com 